Artigo original

Hegemonia - Revista Eletrônica de Relações Internacionais do Centro

Universitário Unieuro

ISSN: $1809-1261$

UNIEURO, Brasília, número 18, 2016, pp. 215-225.

Recebido em: $12 / 3 / 2016$

Avaliado em: $14 / 4 / 2016$

Aprovado em: 29/5/2016

\title{
Should the government intervene in the economy?
}

\author{
Tito Belchior Silva Moreira ${ }^{1}$, Joaquim Ramalho de Albuquerque ${ }^{2}$, Dany \\ Rafael Fonseca Mendes ${ }^{3}$, e Fernando Antonio R. Soares ${ }^{4}$
}

\begin{abstract}
This paper discuss the effects of the governmental intervention on the economy based on Austrian and Keynesian School approach. In this sense, we show that the Austrian theory of crises is nothing more than a particular application of the theory about the deeds of wrong coordination of government's intervention in the areas of fiscal, monetary and credit, which always originates in a systematic discoordination (intra and inter-temporal) of the real economy productive structure. In other words, the crises are the results of government's interventions through economic policies.
\end{abstract}

Key words: Government's interventions, Austrian School, Hayek, Mises.

Resumo: Este artigo discute os efeitos da intervenção governamental na economia com base nas abordagens Austríaca e Keynesiana. Neste sentido, nós mostramos que a teoria austríaca de crise é nada mais do que uma aplicação particular da teoria de coordenação errada de intervenção do governo nas políticas fiscal, monetária e creditícia, na qual sempre redunda em uma descoordenação sistemática (intra e intertemporal) da estrutura produtiva da economia real. Em outras palavras, as crises são resultantes das intervenções governamentais por meio das políticas econômicas.

Palavras chave: Intervenções governamentais, escola Austríaca, Hayek, Mises.

\footnotetext{
${ }^{1}$ Doutor em Economia pela UnB, docente da Universidade Católica de Brasília.

2 Mestre em Economia, servidor do Tribunal de Contas da União.

3 Mestre em Direito.

${ }^{4}$ Doutor em Economia pela UnB, docente da Universidade Católica de Brasília.
} 
Artigo original

Hegemonia - Revista Eletrônica de Relações Internacionais do Centro Universitário Unieuro

ISSN: $1809-1261$

UNIEURO, Brasília, número 18, 2016, pp. 215-225.

\section{Introduction}

The impact of the crisis of subprime in emerging countries, in general, was much lower than in developed countries. The intensity of the impact of the crisis affected different sectors of the economy in different ways. The effects of the U.S. housing market crisis on the financial market and the level of economic activities of the world's major economies propitiated a strong resonant of voices of Economists who advocate for greater state intervention in the economy, as opposed to economists who advocate for greater freedom for the markets.

On one side, the efforts of the governments of the European Common Market (ECM) and the U.S., through fiscal, monetary and credit expansion, minimized the effects on production and employment and provided liquidity to the financial system of these countries in the first moment. Moreover, in a second moment, the result of expansionary fiscal policy has led to serious imbalances in macroeconomic fundamentals due to high deficits and the sharp increase of the debts of these countries, especially to some economies of the ECM, such as Greece, Portugal, Spain, Italy, among others. Such imbalances in the macroeconomics fundamentals contributed to increasing distrust of economic agents about the capability of governments to honor their commitments with the creditors and have contributed to undermine the credibility of economic policies of the respective governments.

In this context, we discuss the effects of the governmental intervention on the economy based on Austrian and Keynesian School approach. Following this brief introduction, section 2 makes a discussion of the theorists who discussed interventionism and the section 3 presents the final remarks. 
Artigo original

Hegemonia - Revista Eletrônica de Relações Internacionais do Centro Universitário Unieuro

ISSN: $1809-1261$

UNIEURO, Brasília, número 18, 2016, pp. 215-225.

2. Government Economic Intervention

The topic interventionism was deeply and thoroughly discussed and analyzed by Ludwig von Mises based on unchangeable economic principles, characteristic of the Austrian School that had predecessors like Carl Menger and Eugen von Bohm-Bawerk and Friedrich Hayek as contemporary ${ }^{5}$. When dealing with interventionism Mises referred to the theories and economic and social policies implemented in the Weimar Republic in Germany in the 1920s.

Though it is almost a century ago, the discussion raised by Mises is still update and important due to the fact that the same notions of state interventionism still lingers. A good example was the American presidential election. On one hand the electoral campaign to re-election of the Democratic candidate, whose speech was based on interventional practice and on the other hand the Republican candidate who advocates clearly a less interventionist government.

Democrats were accused by The Republicans of pursuing a model in which it is the state that has to promote social welfare; this model has proven to be a failure in their point of view, given the current situation of the European countries. Democrats accused Republicans of proposing to abandon the disadvantaged population in the midst of the crisis hangover, reducing or eliminating government support for social programs, such as the recent achievement of access of the poor to public health programs.

This article has no intention to assess who is right nor wrong because this is an issue that possibly will still be present in about another century. The aim is to address the two poles of the debate. On one side are shown the main arguments of the critics of interventionism, made of the economists of the Austrian School, with emphasis on the classical writings

\footnotetext{
${ }^{5}$ Constantino (2009) and Soto (2010) analyzed the legacy of the Austrian School.
} 
Artigo original

Hegemonia - Revista Eletrônica de Relações Internacionais do Centro Universitário Unieuro

ISSN: $1809-1261$

UNIEURO, Brasília, número 18, 2016, pp. 215-225.

of von Mises ${ }^{6}$. On the other hand, the already well known but no less important arguments of the Keynesian School. A brief discussion will be made as regards to Keynes and Hayek's approach.

The issues of interventionism presented by Mises areas follows i) What are the consequences of government's interventions and other instances in the system of private property?, ii) will it be possible to achieve the expected result of these interventions'. Thus, Mises (1977, 2010a) defines intervention as "...a restrictive rule imposed by the government agency, which forces the owners of the means of production and entrepreneurs to employ these means in a different manner as will normally be employed". The author distinguishes two types of rules. The first rule, called "production constraints", reduces or hinders (directly) economic output. The second, which is called "interference in the pricing structure," tries to fix prices different from that of the market.

A classic example of output restrictions or constraints on the supply side of the economy refers to the taxation of imports or even restricting the amount of imported goods, which is the same as a protectionist policy. In the short term the government usually achieves its objectives, that is, maintaining the level of production and employment in the sector benefited. But that does not mean that the goal of intervention is achieved in the medium and long term, since measures restricting production results to decline in labor productivity and therefore restricts supply and also the social dividend (Mises: 2010b, 2011). In this sense, protectionism ends up making the sector benefited less competitive. And when the government promotes protectionism of some specific sectors, ends up prioritizing less productive activities, at the expense of more productive.

\footnotetext{
${ }^{6}$ Highlights that the intention is to make a brief explanation of the main ideas of von Mises about o interventionism and that more detail about this complex topic could be seen in the author's books translated and edited by the Institute of Ludwig von Mises Brazil and by Institute Liberal an example of Mises (1979, 2006).
} 
Artigo original

Hegemonia - Revista Eletrônica de Relações Internacionais do Centro Universitário Unieuro

ISSN: $1809-1261$

UNIEURO, Brasília, número 18, 2016, pp. 215-225.

Mises (1977, 2010a) argues that the effects of interference by taxation, which consists of grabbing some income or wealth, may be partly identical to the constraints of production. In this context, the result is always the same: a certain investment of labor and capital yields less with restriction than without it, that is, less capital and labor is invested in production if the government increases the disincentive of the sector via increased taxes. In short, the relation cost/benefit of the intervention needs a better investigation. It needs to be known, if the benefits generated by the interventionist policies outweigh the costs in the medium and long term.

Regards to above mentioned context, entrepreneurs complain about the high tax burden. The rulers are concerned or should be worried about the risk of "killing the goose that lays the golden eggs." However, for Mises $(1966,2010 c)$, the crux of the issue is the taxation paradoxical fact that the more taxes are increased, the more weakened the market economy is and consequently the tax system itself. Thus, the author argues, there is an apparent incompatibility between the preservation of private property and confiscatory measures. Each tax itself as well as the the tributary system as a whole become self destructive when they exceed certain limits.

The second rule refers to interference through price control. The price control measures aim to set prices, wages and interest rates at values different from those that would prevail if there were no interference (Mises: 2010b, 2011).

Particularly important are the measures that establish minimum wage, which can be determined directly by the government or indirectly through political activity of the labor unions (Mises: 1977, 2010a). If a minimum wage (real) that exceeds the free market level is imposed on the private sector, the production costs of enterprises or industries will 
Artigo original

Hegemonia - Revista Eletrônica de Relações Internacionais do Centro Universitário Unieuro

ISSN: $1809-1261$

UNIEURO, Brasília, número 18, 2016, pp. 215-225.

experience a rise in the cost of production, as result the final price of the product will raise, consequently, sales will decrease resulting to unemployment. When Mises refers to wages, he is considering the real minimum wage.

The arguments mentioned are valid for any price determined by the market that suffers interference from the government. When the government sets the prices of factors of production above the free market price, there is unemployment of factors. If otherwise, the factors are employed.

Mises (2010b, 2011) comments on the political consequences of unemployment in considering the relationship between public opinion, labor unions and government. The author argues that the public opinion are of the view that unemployment is a proof of the failure of the economy and that it does not know that the cause of permanent mass unemployment is due to wage policy advocated by the labor unions and government's support to such policies. He also argues that, to public opinion as well as some economists, technological progress increases unemployment.

In the presence of the unemployment situation, the government and labor unions recommend the reduction of working hours and public programs works in order to create employment. Mises argues that with the reduction of working hours without wages reduction or unchanged unless proportionally increases wages per hours worked and therefore ends up increasing unemployment. He also argues that if spending on public works is financed by raising taxes or issuing bonds, the situation does not change. The resources used in these projects are taken away from others, and the increase of employment opportunities in a sector of the economy is neutralized by the reduction in another sector of the economy. 
Artigo original

Hegemonia - Revista Eletrônica de Relações Internacionais do Centro Universitário Unieuro

ISSN: $1809-1261$

UNIEURO, Brasília, número 18, 2016, pp. 215-225.

Finally, policymakers resort to credit expansion and inflation. In a context of increase of prices and real wages reduction, the unions' demands for higher wages or wage losses intensify. Misses (2010b, 2011) cautiously appointed to the fact that currency devaluation and inflation can succeed in some cases, soften the effects of union policies and temporarily reduce the growth of unemployment.

Soto (2010) argues that the Austrian school considers the interest rate as a market price, determined by subjective valuations of intertemporal preference, which is used to calculate the current value of the future stream of income towards which the market price of each capital asset is based. The manipulation (intervention) of the interest rate by the central banks and fractional reserve banking system to generate recurring cycles of expansion (artificial) and recession.

The major work of Mises $(1966,2010 \mathrm{c})$ includes the development of a theory of business cycles, more lately became known as the "Austrian theory of the business cycle." The author shows that the creation of expansionary credit and deposits without a corresponding effective savings (fiduciary means), caused by a banking system based on fractional reserve ratio directed by a central bank not only generated a cyclical and uncontrolled growth of the money supply, but also to materialize in the creation of ex nihilo of credits at interest rates artificially low, inevitably gave rise to a "flare" artificial and unsustainable production processes. Thus, the processes tend, improperly, to become excessively capital-intensive (Soto, 2010).

According to Mises, the inflationary process resulting from the credit expansion would tend to reverse, causing a crisis or economic recession. The investment decision errors induced by the expansion of credit will become clear so that entrepreneurs will perceive the need for liquidation and reallocation of resources wrongly invested. 
Artigo original

Hegemonia - Revista Eletrônica de Relações Internacionais do Centro Universitário Unieuro

ISSN: $1809-1261$

UNIEURO, Brasília, número 18, 2016, pp. 215-225.

On the other hand, against the arguments of the Austrian school, Keynes shows that crises are the result of insufficient effective demand in relation to installed production capacity. He shows that aggregate demand is a result of demand for consumer goods and investment goods. Consumption depends on income and since propensity to consume of households tends to be stable, the aggregate consumption could not be the source of instability in effective demand. On the other hand, with the inclusion of uncertainty in the business world, the investment decision of the entrepreneur becomes very sensitive to the feelings of pessimism or optimism regards to the expected business environment ${ }^{7}$.

Keynes argued that investment depends on the marginal efficiency of capital and the interest rate, such that the first factor is determined from the income expectations and the current bid price of the capital asset. So, expectations and uncertainty of investment decision-makers about the future of the economy become the main determinant of the fluctuation of effective demand in the economy. Due to the lack of demand resulting from the failure of the free market, according to Keynes, arises the need for a regulator of the economy. In this context, the Keynesians argue that the state, based on expansionary fiscal and monetary policies, can mitigate the effects of recessions and depressions.

\section{Final Remarks}

Hayek who devoted much of his academic activities to the study of cycles, following the theoretical line initiated by Mises, participated in several controversies on monetary theory, capital and cycles with Keynes and academicians of the Chicago School (Soto, 2010). For Hayek the fiscal and monetary manipulations recommended by Keynesians and

7 For a better understanding of the work of Keynes, see Keynes (1982) and Hansen (1987). 
Artigo original

Hegemonia - Revista Eletrônica de Relações Internacionais do Centro Universitário Unieuro

ISSN: $1809-1261$

UNIEURO, Brasília, número 18, 2016, pp. 215-225.

monetarists generate serious distortions in the market intertemporal coordination. Wapshott (2011) makes a discussion on academic trajectories and the controversies between John Maynard Keynes and Friedrich von Hayek who are the central characters, but also considers economists like Milton Friedman and John Kenneth Galbraith. According to the author, the big question is as follows: should the government intervene in the economy? He argues that this discussion is the most important economic battle of our time. Wapshott (2011) brings this controversy discussed by many economists since the 1920 s and that continues till today, with the advent of the subprime crisis.

\section{References}

Constantino, Rodrigo (2009). Economia do Indivíduo. O legado da Escola Austríaca. Instituto Ludwig Von Mises Brasil, $1^{\text {a }}$ Edição.

Hansen, Alvin H. (1987). Guia para Keynes. Editora Revista dos Tribunais Ltda. $2^{a}$ edição, Edições Vértice.

Keynes, John Maynard (1982). A Teoria Geral do Emprego, do Juro e da Moeda. $1^{\text {a }}$ edição, Editora Atlas S.A.

Mises, Ludwig von (1966). Human action: a treatise on economics. Edition: Chicago, H. Regnery Co.

(1977). A critique of interventionism. Edition: New Rochelle, N.Y.: Arlington House.

(1979). As Seis Lições. Instituto Liberal e Instituto Ludwig Von Mises Brasil, 7ª Edição.

(2010 a). Uma crítica ao intervencionismo. Instituto Liberal e Instituto Ludwig Von Mises Brasil, 2a Edição.

(2010 b). Intervencionismo. Uma Análise Econômica. Instituto Ludwig Von Mises Brasil, 2a Edição. 
Artigo original

Hegemonia - Revista Eletrônica de Relações Internacionais do Centro Universitário Unieuro

ISSN: 1809-1261

UNIEURO, Brasília, número 18, 2016, pp. 215-225.

(2010 c). Ação Humana: Um Tratado de Economia. Instituto Ludwig Von Mises Brasil, $3^{a}$ Edição.

(2006). Economic policy: thoughts for today and tomorrow. By

Bettina Bien Greaves. Third Edition: Ludvig von Mises Institute, Auburn, Alabama.

(2011). Interventionism: an economic analysis. By Bettina Bien Greaves. Edition: Indianapolis, Ind.: Liberty Fund.

Soto, Jesus Huerta de (2010). A Escola Austríaca. Instituto Ludwig Von Mises Brasil, 2ª Edição.

Wapshott, Nicholas (2011). Keynes and Hayek: The Clash that Defined Modern Economics. W.W. Norton \& Company, New York. 